\title{
Nitric Oxide-Releasing Chitosan Oligosaccharides as Antibacterial Agents
}

\author{
Yuan Lu, Danielle L. Slomberg, and Mark H. Schoenfisch ${ }^{*}$ \\ Department of Chemistry, The University of North Carolina at Chapel Hill, Chapel Hill, NC 27599
}

\begin{abstract}
Secondary amine-functionalized chitosan oligosaccharides of different molecular weights (i.e., $\sim 2500,5000,10000$ ) were synthesized by grafting 2-methyl aziridine from the primary amines on chitosan oligosaccharides, followed by reaction with nitric oxide (NO) gas under basic conditions to yield $\mathrm{N}$-diazeniumdiolate NO donors. The total NO storage, maximum NO flux, and half-life of the resulting NO-releasing chitosan oligosaccharides were controlled by the molar ratio of 2methyl aziridine to primary amines (e.g., 1:1,2:1) and the functional group surrounding the $\mathrm{N}$ diazeniumdiolates (e.g., polyethylene glycol (PEG) chains), respectively. The secondary aminemodified chitosan oligosaccharides greatly increased the NO payload over existing biodegradable macromolecular NO donors. In addition, the water-solubility of the chitosan oligosaccharides enabled their penetration across the extracellular polysaccharides matrix of Pseudomonas aeruginosa biofilms and association with embedded bacteria. The effectiveness of these chitosan oligosaccharides at biofilm eradication was shown to depend on both the molecular weight and ionic characteristics. Low molecular weight and cationic chitosan oligosaccharides exhibited rapid association with bacteria throughout the entire biofilm, leading to enhanced biofilm killing. At concentrations resulting in 5-log killing of bacteria in Pseudomonas aeruginosa biofilms, the NOreleasing and control chitosan oligosaccharides elicited no significant cytotoxicity to mouse fibroblast L929 cells in vitro.
\end{abstract}

\section{Keywords}

Drug release; Nitric oxide; Chitosan; Anti-bacterial; Biodegradable

\section{Introduction}

Bacteria in nature exist in two states - free-floating planktonic bacteria and bacterial biofilms.[1] While many antimicrobial agents have proved effective against planktonic bacteria, medically relevant infections including the infections associated with medical implants, non-healing wounds, diabetic mellitus, and cystic fibrosis are often caused by bacterial biofilms.[2-5] Biofilms are communities of microorganisms adhered to a surface and surrounded by a self-produced extracellular polysaccharide (EPS) matrix that impedes immune response.[6, 7] Compared to planktonic bacteria, biofilm-based bacteria are more resistant to antibiotics due to several specific defense mechanisms including inefficient penetration of antimicrobial agents cross EPS.[8,9] For example, the antibiotic dose to kill

\footnotetext{
(C) 2013 Elsevier Ltd. All rights reserved.

*Address correspondence to Dr. Mark H. Schoenfisch, schoenfisch@unc.edu, Fax: 919-966-2388.
}

Publisher's Disclaimer: This is a PDF file of an unedited manuscript that has been accepted for publication. As a service to our customers we are providing this early version of the manuscript. The manuscript will undergo copyediting, typesetting, and review of the resulting proof before it is published in its final citable form. Please note that during the production process errors may be discovered which could affect the content, and all legal disclaimers that apply to the journal pertain. 
bacteria in biofilms may be 1000 times the dose required to kill planktonic bacteria.[10] As such, new antimicrobial agents capable of eradicating mature biofilms are urgently needed.

Nitric oxide (NO), a diatomic free radical produced endogenously, plays a key role in the mammalian immune response to pathogens.[11-13] The bactericidal properties of NO are attributed to the nitrosative and oxidative stress exerted by its reactive byproducts such as dinitrogen trioxide and peroxynitrite, ultimately leading to the disruption of bacteria membrane.[13] Nitric oxide-releasing materials have been widely developed for the use in a number of different biomedical applications, many related to pathogen killing.[14-17] Recent research has demonstrated the antimicrobial efficacy of small molecule (e.g., 1-[2(carboxylato)pyrrolidin-1-yl]diazen-1-ium-1,2-diolate (PROLI/NO)) and macromolecular (e.g., silica nanoparticles and dendrimers) NO-releasing vehicles against both Grampositive and Gram-negative bacteria, including methicillin-resistant Staphylococcus aureus (MRSA).[18-25] Nitric oxide-releasing macromolecular scaffolds (e.g., silica nanoparticles and dendrimers) are particularly attractive due to enhanced bactericidal activity against planktonic bacteria and biofilms compared to small molecule NO donors (e.g., PROLI/NO). [20-23] Although NO-releasing silica particles proved effective at eradicating established biofilms, the lack of biodegradability greatly hinders the clinical utility of silica-based NOreleasing vehicles as antimicrobial agents.

Biodegradable NO-releasing materials have been developed as implant coatings (e.g., poly(diol citrate) elastomers[26] and polyesters [27-29]) to inhibit biofilm formation rather than eradicate established biofilms. To enable more efficient killing of biofilms, the design of new scaffolds is necessary to allow efficient EPS penetration and NO delivery to the bacteria embedded in the biofilms. Chitosan, the second most abundant natural biopolymer, has been widely used for biomedical applications including tissue engineering, drug delivery, and antimicrobial agents due to its biocompatibility, biodegradability and cationic composition.[30-33] The use of chitosan derivatives as NO-releasing scaffolds has also been investigated since these materials contain large concentrations of primary amines, necessary for $\mathrm{N}$-diazeniumdiolate NO donor formation.[34-36] Unfortunately, previously reported $N$-diazeniumdiolate-functionalized chitosan polysaccharides have been characterized by low $N$-diazeniumdiolate conversion efficiency and NO storage $(\sim 0.2 \mu \mathrm{mol} /$ $\mathrm{mg}$ ), likely the result of chitosan insolubility under the basic conditions required for $\mathrm{N}$ diazeniumdiolate formation.[34-36] Additionally, the effectiveness of chitosan polysaccharides is a concern due to insolubility under physiological conditions.[37],[38] To obtain $N$-diazeniumdiolate-functionalized chitosan derivatives with greater NO storage, we synthesized chitosan oligosaccharides that are soluble under both neutral and basic conditions and highly effective against Pseudomonas aeruginosa biofilms.

\section{EXPERIMENTAL}

\section{Materials and Methods}

Medium molecular weight chitosan, 2-methyl aziridine (MAz), rhodamine B isothiocyanate (RITC), poly(ethylene glycol) methyl ether acrylate (average $\mathrm{Mn}=480)(\mathrm{PEG})$, fetal bovine serum (FBS), Dulbecco's Modified Eagle's Medium (DMEM), phenazine methosulfate (PMS), 3-(4,5-dimethylthiazol-2-yl)-5-(3-carboxymethoxyphenyl)-2-(4-sulfophenyl)-2Htetrazolium inner salt (MTS), trypsin, phosphate buffered saline (PBS), and penicillin streptomycin (PS) were purchased from the Aldrich Chemical Company (Milwaukee, WI). Pseudomonas aeruginosa (ATCC \#19143) was obtained from the American Type Culture Collection (Manassas, VA). Trypic soy broth (TSB) and Tryptic soy agar (TSA) are purchased from Becton, Dickinson, and Company (Franklin Lakes, NJ). L929 mouse fibroblasts (ATCC \#CCL-1) were obtained from the University of North Carolina Tissue Culture Facility (Chapel Hill, NC). Distilled water was purified with a Millipore Milli-Q 
Gradient A-10 water purification system (Bedford, MA). Syto 9 green fluorescent nucleic acid stain was purchased from Life Technologies (Grand Island, NY). Common laboratory salts and solvents were purchased from Fisher Scientific (Pittsburgh, PA). All materials were used as received without further purification unless noted otherwise. Nuclear magnetic resonance (NMR) spectra were recorded on a $400 \mathrm{MHz}$ Bruker instrument. Elemental (carbon, hydrogen, and nitrogen or CHN) analysis was performed using a PerkinElmer Elemental Analyzer Series 2400 instrument (Waltham, MA).

\section{Synthesis of Chitosan Oligosaccharides}

Chitosan oligosaccharides were prepared by oxidative degradation using hydrogen peroxide. Medium molecular weight chitosan $(2.5 \mathrm{~g})$ was suspended in a hydrogen peroxide solution ( 15 or $30 \mathrm{wt} \%$ ) under stirring for $1 \mathrm{~h}$ at $65-85^{\circ} \mathrm{C}$. Following the removal of undissolved chitosan by filtration, chitosan oligosaccharides were precipitated from solution by adding acetone to the filtrate. The precipitate was collected by centrifugation, washed twice with ethanol, and dried under vacuum at room temperature. The viscosity of the chitosan oligosaccharides was measured in a solution of $\mathrm{NaCl}(0.20 \mathrm{M})$ and $\mathrm{CH}_{3} \mathrm{COOH}(0.10 \mathrm{M})$ at $25^{\circ} \mathrm{C}$ using an Ubbleohde capillary viscometer. Oligosaccharide molecular weight was determined using the classic Mark-Houwink equation (i.e., [ $\eta]=1.81 \times 10^{-3} \mathrm{M}^{0.93}$ ).[39]

\section{Synthesis of Secondary Amine-Functionalized Chitosan Oligosaccharides (Scheme 1)}

2-methyl aziridine (MAz) grafted chitosan oligosaccharides were synthesized following a previously reported procedure.[40] Briefly, a mixture of concentrated $\mathrm{HCl}(11 \mu \mathrm{L})$, water $(100 \mu \mathrm{L})$ and MAz with a 1:1 (Chitosan 1) or 2:1 (Chitosan 2) molar ratio to primary amines on the chitosan oligosaccharides was added dropwise to a solution of chitosan oligosaccharides $(100 \mathrm{mg})$ in deionized water $(5 \mathrm{~mL})$. The resulting solution was stirred at room temperature for $5 \mathrm{~d}$, and then at $75^{\circ} \mathrm{C}$ for $24 \mathrm{~h}$. The product was purified by dialysis and collected by lyophilization. Any high molecular weight poly(2-methyl aziridine) in the product was removed by washing with methanol, and the resulting material was dried under vaccum at room temperature. Chitosan 2 was then dissolved in water at $\mathrm{pH}$ 10.0. The primary amine on the chitosan oligosaccharides was functionalized by adding poly(ethylene glycol) methyl ether acrylate to generate Chitosan 3. The resulting PEG-functionalized chitosan oligosaccharide derivative was purified by dialysis and collected by lyophilization.

${ }^{1} \mathrm{H}$ NMR data of Chitosan 1 and Chitosan 2 (400 MHz, $\left.\mathrm{CD}_{3} \mathrm{OD}, \delta\right): 0.8-1.1$ $\left(\mathrm{NH}_{2} \mathrm{CH}\left(\mathrm{CH}_{3}\right) \mathrm{CH}_{2} \mathrm{NH}\right), 1.9\left(\mathrm{C} 7: \mathrm{CHNHCOCH}_{3}\right), 2.3-2.7\left(\mathrm{NH}_{2} \mathrm{CH}\left(\mathrm{CH}_{3}\right) \mathrm{CH}_{2} \mathrm{NHCH}, \mathrm{C} 2\right.$ : $\left.\mathrm{NH}_{2} \mathrm{CH}\left(\mathrm{CH}_{3}\right) \mathrm{CH}_{2} \mathrm{NHCH}\right), 3.3-4.0\left(\mathrm{C} 3, \mathrm{C} 4, \mathrm{C} 5, \mathrm{C} 6: \mathrm{OHCH}, \mathrm{OCHCH}(\mathrm{OH}) \mathrm{CH}\left(\mathrm{NH}_{2}\right) \mathrm{CH}\right.$, $\left.\mathrm{OHCH}_{2} \mathrm{CH}, \mathrm{OHCH}_{2} \mathrm{CH}\right), 4.4\left(\mathrm{Cl}: \mathrm{OCH}\left(\mathrm{CHNH}_{2}\right) \mathrm{O}\right) .{ }^{1} \mathrm{H}$ NMR data of Chitosan 3 (400 $\left.\mathrm{MHz}, \mathrm{CD}_{3} \mathrm{OD}, \delta\right): 0.8-1.1\left(\mathrm{NH}_{2} \mathrm{CH}\left(\mathrm{CH}_{3}\right) \mathrm{CH}_{2} \mathrm{NH}\right), 1.9$ (C7: $\left.\mathrm{CHNHCOCH}_{3}\right), 2.3-2.7$ $\left(\mathrm{NH}_{2} \mathrm{CH}\left(\mathrm{CH}_{3}\right) \mathrm{CH}_{2} \mathrm{NHCH}, \mathrm{C} 2: \mathrm{NH}_{2} \mathrm{CH}\left(\mathrm{CH}_{3}\right) \mathrm{CH}_{2} \mathrm{NHCH}\right), 3.2\left(\mathrm{OCH}_{2} \mathrm{CH}_{2} \mathrm{OCH}_{3}\right), 3.3-4.0$ $\left(\mathrm{OCH}_{2} \mathrm{CH}_{2} \mathrm{O}\right.$ and $\mathrm{C} 3, \mathrm{C} 4, \mathrm{C} 5, \mathrm{C} 6: \mathrm{OHCH}, \mathrm{OCHCH}(\mathrm{OH}) \mathrm{CH}\left(\mathrm{NH}_{2}\right) \mathrm{CH}, \mathrm{OHCH}_{2} \mathrm{CH}$, $\left.\mathrm{OHCH}_{2} \mathrm{CH}\right), 4.4\left(\mathrm{Cl}: \mathrm{OCH}\left(\mathrm{CHNH}_{2}\right) \mathrm{O}\right)$.

\section{Synthesis of $\boldsymbol{N}$-Diazeniumdiolate-Functionalized Chitosan Oligosaccharides}

Secondary amine-functionalized chitosan oligosaccharides (Chitosan 1, Chitosan 2, and Chitosan 3) and $5.4 \mathrm{mM}$ sodium methoxide $(75 \mu \mathrm{L})$ were added to a methanol/water mixture (2 mL) of different v/v ratios (e.g., 1:0, 9:1, 8:2, 7:3, 6:4). The suspension was added to vials in a Parr hydrogenation vessel, which was purged rapidly (5-10 s) with argon three times followed by three longer argon purge cycles $(10 \mathrm{~min})$ to remove residual oxygen from the solution. The Parr hydrogenation vessel was then pressurized to $10 \mathrm{~atm}$ with NO gas purified over $\mathrm{KOH}$ pellets (to remove $\mathrm{NO}$ degradation products) and maintained at 10 atm for $3 \mathrm{~d}$. The same argon purging protocol was performed to remove unreacted $\mathrm{NO}$ and degradation products from the solution prior to removing the vials from the vessel. 


\section{Characterization of Nitric Oxide Storage and Release}

$\mathrm{N}$-diazeniumdiolate-functionalized chitosan oligosaccharides ( $1 \mathrm{mg}$ ) (Chitosan 1/NO, Chitosan 2/NO, Chitosan 3/NO) in the water/methanol mixture were added into a sample vessel containing $30 \mathrm{~mL}$ deoxygenated phosphate buffered saline (PBS) $(10 \mathrm{mM}, \mathrm{pH}=7.4)$ at $37^{\circ} \mathrm{C}$, which initiated NO release. To quantify the NO released, the solution was purged with nitrogen at a flow rate of $70 \mathrm{~mL} / \mathrm{min}$ to carry the liberated $\mathrm{NO}$ to the analyzer. Additional nitrogen flow was supplied to the vessel to match the collection rate of the instrument $(200 \mathrm{~mL} / \mathrm{min})$. The analysis of $\mathrm{NO}$ was terminated when the $\mathrm{NO}$ release levels fell to below $10 \mathrm{ppb} \mathrm{NO/mg} \mathrm{chitosan} \mathrm{oligosaccharides.} \mathrm{Chemiluminescence} \mathrm{data} \mathrm{for} \mathrm{the}$ NO-releasing chitosan oligosaccharides were represented as: 1) total amount of NO release $(\mathrm{t}[\mathrm{NO}], \mu \mathrm{mol} \mathrm{NO} / \mathrm{mg}$ of secondary amine-functionalized chitosan oligosaccharides); 2 ) the maximum flux of $\mathrm{NO}$ release $\left([\mathrm{NO}]_{\max }, \mathrm{ppb} / \mathrm{mg}\right.$ of secondary amine-functionalized chitosan oligosaccharides); and 3) the half-life of $\mathrm{NO}$ release $\left(\mathrm{t}_{1 / 2}\right)$.

\section{Synthesis of Fluorescently-Labeled Chitosan Oligosaccharides}

Fluorescently-labeled chitosan oligosaccharides were prepared following a previously reported procedure.[41] Briefly, chitosan oligosaccharides $(50 \mathrm{mg})$ were dissolved in water $(2 \mathrm{~mL})$ at $\mathrm{pH}$ 9.0. Rhodamine B isothiocyanate (RITC) was added to the solution in a 1:100 molar ratio to the primary amine of the chitosan oligosaccharides prior to the grafting of 2methyl aziridine. The solution was stirred at room temperature for $3 \mathrm{~d}$ in the dark.

Subsequent dialysis and lyophilization yielded the RITC-labeled chitosan oligosaccharides.

\section{Bactericidal Assays against Planktonic Pseudomonas aeruginosa}

P. aeruginosa bacterial cultures were grown from a frozen $\left(-80^{\circ} \mathrm{C}\right)$ stock overnight in TSB at $37^{\circ} \mathrm{C}$. A $500 \mu \mathrm{L}$ aliquot of the resulting suspension was added into $50 \mathrm{~mL}$ fresh TSB and incubated at $37^{\circ} \mathrm{C}$ for $\sim 2 \mathrm{~h}$ until the concentration reached $\sim 1 \times 10^{8}$ colony forming units $(\mathrm{CFU}) / \mathrm{mL}$, as confirmed by the $\mathrm{OD}_{600}$, replicate plating and enumeration on nutrient agar. A working bacterial stock was generated by plating the bacterial suspension on TSA and incubating at $37^{\circ} \mathrm{C}$ overnight. The TSA bacterial stocks were prepared weekly and stored at $4{ }^{\circ} \mathrm{C}$. For bactericidal assays, colonies of $P$. aeruginosa were taken from the TSA plate, dispersed in $3 \mathrm{~mL} \mathrm{TSB}$, and incubated at $37^{\circ} \mathrm{C}$ overnight. A $500 \mu \mathrm{L}$ aliquot of culture was added to $50 \mathrm{~mL}$ fresh TSB and incubated to a concentration of $\sim 1 \times 10^{8} \mathrm{CFU} / \mathrm{mL}$. The bacteria was collected by centrifugation, resuspended in PBS, and diluted to $\sim 1 \times 10^{6} \mathrm{CFU} /$ $\mathrm{mL}$. The bactericidal efficacy of NO-releasing chitosan oligosaccharides against $P$. aeruginosa was evaluated by incubating the bacteria suspension with NO-releasing chitosan oligosaccharides at $37^{\circ} \mathrm{C}$. At $4 \mathrm{~h}, 100 \mu \mathrm{L}$ aliquots of the bacterial suspensions were removed, diluted 10 -fold in PBS, plated on TSA, and incubated overnight at $37^{\circ} \mathrm{C}$. The minimum concentration of NO-releasing chitosan oligosaccharides that resulted in a 3-log reduction of bacterial viability was defined as the minimum bactericidal concentration (MBC) for planktonic studies.

\section{Growth of $P$. aeruginosa Biofilms}

A CDC bioreactor (Biosurface Technologies, Bozeman, MT) was used to grow $P$. aeruginosa biofilms over a $48 \mathrm{~h}$ period. Briefly, medical grade silicone rubber substrates were mounted in coupon holders prior to assembling the reactor. The assembled reactor was then autoclaved. The reactor effluent line was clamped, and 1\% (v/v) sterile TSB (500 mL) was added aseptically. P. aeruginosa was then cultured in TSB to $10^{8} \mathrm{CFU} / \mathrm{mL}$. The reactor was inoculated with an aliquot $(1 \mathrm{~mL})$ of this bacterial suspension at a final concentration $\sim 2$ $\times 10^{5} \mathrm{CFU} / \mathrm{mL}$. The reactor was incubated at $37{ }^{\circ} \mathrm{C}$ for $24 \mathrm{~h}$ with slow stirring $(150 \mathrm{rpm})$. Following this "batch phase" growth, the reactor media was refreshed continuously with $0.33 \%$ (v/v) TSB at $6 \mathrm{~mL} / \mathrm{min}$ for another $24 \mathrm{~h}$ through the effluent line. 


\section{Treatment of $\boldsymbol{P}$. aeruginosa Biofilms with Chitosan Oligosaccharides}

$P$. aeruginosa biofilms grown on silicone rubber substrates were exposed to chitosan oligosaccharide in PBS with slight agitation $\left(37^{\circ} \mathrm{C}, 24 \mathrm{~h}\right)$ to determine the minimum bactericidal concentration (MBC) necessary to elicit a 5-log reduction in viability. At $24 \mathrm{~h}$, samples were then sonicated and vortexed to disrupt the biofilm. Aliquots $(100 \mu \mathrm{L})$ of the bacteria/chitosan suspensions were diluted and plated on TSA. After incubating the TSA plates overnight at $37^{\circ} \mathrm{C}$, bacteria viability was determined by counting observed colonies. Of note, the limit of detection for this selected plate counting method is $2.5 \times 10^{3} \mathrm{CFU} / \mathrm{mL}$. As such, biofilm growth conditions were selected to accurately represent a 5-log reduction in viability for biofilms.

\section{Confocal Microscopy}

P. aeruginosa was cultured in TSB to a concentration of $\sim 1 \times 10^{8} \mathrm{CFU} / \mathrm{mL}$, collected via centrifugation $(3645 \times g$ for $10 \mathrm{~min})$, resuspended in sterile PBS, and adjusted to $\sim 1 \times 10^{6}$ $\mathrm{CFU} / \mathrm{mL}$. Aliquots of the bacteria solution were incubated in a glass bottom confocal dish for $1.5 \mathrm{~h}$ at $37^{\circ} \mathrm{C}$. A Zeiss 510 Meta inverted laser scanning confocal microscope with a 543 $\mathrm{nm}$ HeNe excitation laser and a LP $585 \mathrm{~nm}$ filter was used to obtain fluorescence images of the rhodamine B isothiocyanate (RITC)-modified chitosan oligosaccharides. The bright field and fluorescence images were collected by a N.A. 1.2 C-apochromat water immersion lens with a 40x objective. Solutions of RITC-labeled NO-releasing chitosan oligosaccharides in PBS $(1.5 \mathrm{~mL})$ were added to the bacteria solution $(1.5 \mathrm{~mL})$ in the glass confocal dish to achieve a final concentration of $150 \mu \mathrm{g} / \mathrm{mL}$. Images were collected every 2 min to characterize the association, if any, of the chitosan oligosaccharides with $P$. aeruginosa temporally. To observe the association of chitosan oligosaccharides with bacteria within biofilms, Established biofilms stained with syto $9(10 \mu \mathrm{M})$ were incubated with RITClabeled chitosan oligosaccharides $(150 \mu \mathrm{g} / \mathrm{mL}$ in PBS) for $2.5 \mathrm{~h}$. Prior to imaging, samples were rinsed with PBS (3x). A Zeiss 510 Meta inverted laser scanning confocal microscope with $488 \mathrm{~nm}$ Ar and $543 \mathrm{~nm}$ HeNe excitation lasers, and a BP 505-530 nm and LP $585 \mathrm{~nm}$ filters, respectively, was used to obtain all confocal images. Fluorescence images were collected with a 20x objective.

\section{In Vitro Cytotoxicity Testing of NO-releasing Chitosan Oligosaccharides}

L929 mouse fibroblasts were grown in DMEM supplemented with $10 \% \mathrm{v} / \mathrm{v}$ fetal bovine serum (FBS) and $1 \mathrm{wt} \%$ penicillin/streptomycin, and incubated in $5 \% \mathrm{v} / \mathrm{v} \mathrm{CO}_{2}$ under humidified conditions at $37^{\circ} \mathrm{C}$. After reaching confluency (80\%), the cells were trypsinized, seeded onto tissue-culture treated polystyrene 96 -well plates at a density of $3 \times 10^{4}$ cells $/ \mathrm{mL}$, and incubated at $37{ }^{\circ} \mathrm{C}$ for $48 \mathrm{~h}$. The supernatant was then aspirated prior to adding fresh $\operatorname{DMEM}(200 \mu \mathrm{L})$ and the NO-releasing chitosan oligosaccharides solution in PBS $(50 \mu \mathrm{L})$ to each well. After incubation at $37^{\circ} \mathrm{C}$ for $24 \mathrm{~h}$, the supernatant was aspirated and a mixture of DMEM/MTS/PMS $(105 / 20 / 1, \mathrm{v} / \mathrm{v} / \mathrm{v})(120 \mu \mathrm{L})$ was added to each well. The absorbance of the resulting colored solution after $1.5 \mathrm{~h}$ incubation at $37^{\circ} \mathrm{C}$ was quantified using a Thermoscientific Multiskan EX plate reader at $490 \mathrm{~nm}$. The mixture of DMEM/MTS/PMS and untreated cells were used as a blank and control, respectively. Cell viability was calculated as follows (Eq. 1).

$$
\text { Cell Viability }=\frac{\left(\text { Absorbance }_{\text {treated cell }}-\text { Absorbance }_{\text {blank }}\right)}{\left(\text { Absorbance }_{\text {untreated cell }}-\text { Absorbance }_{\text {blank }}\right)} \text { Eq.1 }
$$




\section{RESULTS AND DISCUSSION}

Chitosan has been widely used in antitumor, antimicrobial, and wound healing applications due to favorable biocompatibility and the ability to slowly degrade into nontoxic byproducts. [42-45] This polymer has also been modified to store and release NO by functionalizing the primary amines with NO to form $\mathrm{N}$-diazeniumdiolates.[34-36] Unfortunately, the NO storage is rather modest $(\sim 0.2 \mu \mathrm{mol} / \mathrm{mg})$ due to poor solubility of polysaccharides in basic solutions necessary for $\mathrm{NO}$ donor formation.[34-36] To synthesize $N$-diazeniumdiolatefunctionalized chitosan derivatives with improved NO storage, we prepared water-soluble chitosan oligosaccharides by the degradation of chitosan polysaccharides in hydrogen peroxide. An additional benefit of the low-molecular weight (MW < 8000) chitosan oligosaccharides involves their ability to more easily penetrate biofilms.[41, 46] In this regard, we predict that low-molecular weight $N$-diazeniumdiolate-modified chitosan oligosaccharides would have even greater bactericidal activity compared to the polysaccharides.

\section{Synthesis of Secondary Amine-Functionalized Chitosan Oligosaccharides}

A number of strategies have been reported for degrading chitosan into oligomer derivatives. $[40,47]$ Rather than use enzymatic degradation requiring costly enzymes (e.g., chitosanase), we adapted an oxidative degradation strategy using hydrogen peroxide to synthesize chitosan oligosaccharides.[40] Control of the molecular weight $\left(\mathrm{M}_{\mathrm{w}}\right)$ was achieved by varying the concentration of hydrogen peroxide and degradation temperature. The viscosity of the chitosan oligosaccharides was determined in a solution of sodium chloride $(0.20 \mathrm{M})$ and acetic acid $(0.10 \mathrm{M})$ using an Ubbleohde capillary viscometer.[39] In combination with the Mark-Houwink equation (i.e., $[\eta]=1.81 \times 10^{-3} \mathrm{M}^{0.93}$ ), molecular weights were determined as a function of processing conditions. Collectively, larger concentrations of hydrogen peroxide and elevated degradation temperatures led to lower molecular weight chitosan. As shown in Table 1, chitosan oligosaccharides of $\sim 10 \mathrm{kD}$ molecular weight were prepared in $15 \mathrm{wt} \%$ hydrogen peroxide at $65^{\circ} \mathrm{C}$ for $1 \mathrm{~h}$. Increasing the degradation temperature to $85^{\circ} \mathrm{C}$ resulted in significantly smaller size $(\mathrm{MW} \sim 5 \mathrm{kD})$. When both a larger concentration of hydrogen peroxide (i.e., $30 \mathrm{wt} \%$ ) and elevated temperature (i.e., $85^{\circ} \mathrm{C}$ ) were adopted, the molecular weight of chitosan oligosaccharides decreased further $(\sim 2.5$ $\mathrm{kD}$ ) were achieved. As shown in Table 2, the CHN elemental analysis of the oligosaccharides indicated an overall nitrogen content of $6.3 \mathrm{wt} \%$.

To enhance NO storage (secondary amines are more readily converted to NO form due to their increased basicity $[22,48,49])$, the primary amines on the synthesized chitosan oligosaccharides were thus modified by a cationic ring opening of MAz to produce secondary amine functionalities (Scheme 1A). By tuning the ratio of MAz and primary amine (e.g., 1:1 Chitosan 1, 2:1 Chitosan 2), the number of MAz repeating units grafted onto the chitosan oligosaccharides proved tunable (as verified by NMR), leading to a range of secondary amine concentrations and NO storage. To investigate how the local environment surrounding the $N$-diazeniumdiolate NO donors affected the NO-release kinetics, [22] acrylate-functionalized PEG chains were conjugated to the primary amines on Chitosan 2 by the Michael addition reaction to yield PEG-modified scaffolds (e.g., Chitosan 3, Scheme 1B). Grafting of 2-methyl aziridine to the oligosaccharides increased the corresponding nitrogen content from 6.3 to 8.9 and $10.8 \mathrm{wt} \%$ for Chitosan 1 and Chitosan 2, respectively. As expected, the PEGylation of Chitosan 2 led to a corresponding decrease in nitrogen content (3.1 wt\%) (Chitosan 3). 


\section{Synthesis of $\boldsymbol{N}$-Diazeniumdiolate-Modified Chitosan Oligosaccharides}

Reaction of the secondary amine-functionalized chitosan oligosaccharides (Chitosan 1, Chitosan 2, and Chitosan 3) with NO (10 atm under basic conditions) yielded $N$ diazeniumdiolate NO donor-functionalized chitosan oligosaccharides (Chitosan 1/NO, Chitosan 2/NO, and Chitosan 3/NO). The NO conjugation ("charging") solvent dictates the charging efficiency and thus total NO storage.[22] Aqueous solutions were necessary in order to adequately dissolve the chitosan oligosaccharides. Despite the high $\mathrm{pH}$ that should inhibit NO donor breakdown,[49] NO donor formation due to the presence of water was a concern. To examine the influence of water concentration on $N$-diazeniumdiolate conversion efficiency, mixtures of methanol (a common charging solvent)[22, 50] and water were prepared (10:0, 9:1, 8:2, 7:3, and $6: 4 \mathrm{v} / \mathrm{v})$ and the $\mathrm{pH}$ was adjusted to above 10 by adding sodium methoxide.

Chitosan 2/NO-5k was used as a representative oligosaccharide for these studies with the assumption that lower and greater MW chitosan oligosaccharides would behave similarly. The NO release profile for Chitosan 2/NO-5k as a function of the charging solvent are shown in Figure 1. Specific NO-release parameters (e.g., total NO release, maximum flux, and half-life) were extracted from these profiles and are provided in Table 3 . The NO storage increased with increasing water/methanol ratios up to 7:3. The maximum NO storage (using the 7:3 methanol/water charging solvent ratio) was $0.87 \mu \mathrm{mol} / \mathrm{mg}$, roughly $4 \mathrm{x}$ larger than that for previously reported chitosan polysaccharides $(\sim 0.2 \mu \mathrm{mol} / \mathrm{mg})$.[39-41] The improved NO storage may be attributed to the enhanced solubility of Chitosan $\mathbf{2 - 5} \mathbf{k}$ in the charging solvents (e.g., methanol/water 9:1, 8:2, 7:3) relative to methanol. In charging solvent where Chitosan 2-5k was essentially insoluble (e.g., methanol), only secondary amines on the exterior of the Chitosan 2-5k precipitate were accessible to NO, leading to a lower NO donor formation efficiency. In contrast, complete dissolution exposes a significantly greater proportion of secondary amines to the base and NO. At larger water concentrations (i.e., methanol/water $6: 4 \mathrm{v} / \mathrm{v}$ or $40 \%$ water), the NO storage decreased slightly $(\sim 0.76 \mu \mathrm{mol} / \mathrm{mg})$, suggesting destabilization of the $N$-diazeniumdiolate NO donor by water. Chitosan 2/NO-5k exhibited similar NO-release kinetics (e.g., half-life of $\sim 2 \mathrm{~h}$ ) regardless of the charging solvent, indicating that while the chemical structure (e.g., the local environment surrounding $N$-diazeniumdiolates) of the NO-releasing scaffolds dictates NO-release kinetics, variation in charging solvent only affects the total NO storage. Overall, the NO-release data revealed that the optimal charging solvent was methanol/water 7:3 (v/ $v)$. This solvent composition was used for the functionalization of the other secondary amine-functionalized chitosan oligosaccharides (Chitosan 1-5k and Chitosan 3-5k).

The antibacterial efficacy of NO-releasing materials has been reported to be dependent on both NO storage (i.e., payload) and release kinetics.[51] 2-methyl aziridine (MAz) was grafted onto the chitosan oligosaccharides at different feed ratios (i.e., 2:1 and 1:1) to alter the secondary amine functionalization and NO storage. As expected, increasing the feed ratio of 2-methyl aziridine to primary amines from 1:1 (Chitosan 1-5k) to 2:1 (Chitosan 25k) resulted in greater NO storage (e.g., $\sim 0.30$ to $0.87 \mu \mathrm{mol} / \mathrm{mg}$, respectively). As shown in Figure 2, the NO flux and storage of Chitosan 1/NO-5k were lower than Chitosan 2/ NO-5k, a result that is attributable to the smaller amine concentration of Chitosan 1-5k ( 8.9 wt $\%)$ compared to Chitosan 2-5k ( 10.8 wt\%).

To tune the NO-release kinetics of chitosan oligosaccharides further, Chitosan 2-5k was modified with acrylate-functionalized PEG chains (Chitosan 3-5k). As expected, hydrophilic functionalization of the oligosaccharides with PEG facilitated a more aqueous local environment and result in both larger initial NO flux $(\sim 12600 \mathrm{ppb} / \mathrm{mg})$ and faster overall NO release (half-life $\sim 0.15$ h) relative to Chitosan $2-5 k$ (Figure 2).[22] The 
PEGylation of primary amines on Chitosan 2-5k also affected its ionic characteristics by shielding the amine moieties, a key factor influencing the association of chitosan-based materials with bacteria.[38] The distinct NO-release kinetics and ionic characteristics of the resulting NO-releasing chitosan oligosaccharides allowed for the study of how surface charge and NO release affect anti-biofilm activity.

\section{Bactericidal Studies:Planktonic Bacteria}

Control and NO-releasing chitosan oligosaccharides (e.g., Chitosan 1/NO -5k, Chitosan 2/ NO-5k, Chitosan 3/NO -5k) were exposed to Gram-negative $P$. aeruginosa, a pathogen involved in infections associated with burn wounds and cystic fibrosis, to evaluate their ability to kill bacteria.[5, 52] Bacterial viability assays were performed under static conditions to determine the concentration of chitosan required to reduce bacteria viability by $3 \operatorname{logs}$ (i.e., 99.9\% killing), which hereafter will be referred to as the minimum bactericidal concentration or MBC. The amount of NO delivered from NO-releasing chitosan oligosaccharides (Table 4) over the time of the assay (4 h) was also examined to quantitatively assess the NO dose necessary for $99.9 \%$ bacterial killing. Both MBCs and the bactericidal $\mathrm{NO}$ doses required for the chitosan oligosaccharides are provided in Table 5. Each of the NO-releasing chitosan oligosaccharides studied (Chitosan 1/NO-5k, Chitosan

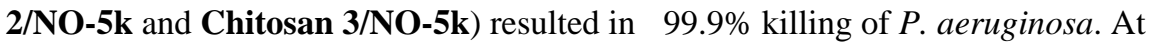
equivalent concentrations, the control (non-NO-releasing) chitosan did not lead to a significant reduction in bacterial viability, indicating $\mathrm{NO}$ as the bactericidal agent (data not shown). Further inspection of the bactericidal NO doses in Table 5 reveals that greater NO levels were required from Chitosan 3/NO-5k compared to Chitosan 1/NO-5k and Chitosan 2/NO-5k to kill $P$. aeruginosa. This behavior may be attributed to decreased interaction between the chitosan oligosaccharides and bacteria membrane. Sun et al. previously reported that positively charged dendrimers associated more readily with bacteria than neutral dendrimers. enhanced bactericidal action was the result of such interactions.[23] The less effective bacteria killing observed for Chitosan 3/NO-5k could stem from the ability of the neutral PEG chains to shield the amine moieties. In contrast, Chitosan 1/ NO-5k and Chitosan 2/NO-5k have positively charged primary amines at pH 7.4 on their exterior that enhance their association with the bacteria and facilitate more localized NO delivery.

To further confirm that the lessened antibacterial activity of Chitosan 3/NO-5k was the result of decreased interactions with the bacteria membrane, confocal microscopy was utilized to compare the association kinetics of Chitosan 3/NO-5k and Chitosan 2/NO-5k with bacteria. Rhodamine B isothiocyanate (RITC)-labeled Chitosan 2/NO-5k and Chitosan 3/NO-5k were synthesized as previously reported.[41] The potential impact of RITC on chitosan-bacteria association was minimized by using small concentration of RITC (i.e., in 1:100 molar ratio to total primary amines). The degree of association of the NOreleasing chitosan oligosaccharides with bacteria was then followed by measuring red fluorescence surrounding the bacteria. As expected, Chitosan 2/NO-5k associated with the bacteria more rapidly (within $24 \mathrm{~min}$ ) than Chitosan 3/NO-5k (86 min) (Figure 3). The fluorescence from Chitosan 2/NO-5k at 42 min was significantly greater than that of Chitosan 3/NO-5k at $110 \mathrm{~min}$, further demonstrating that Chitosan 3/NO-5k associated with the bacteria at a much slower rate due to the PEG (neutral) modification. Further inspection of Chitosan 2/NO-5k and Chitosan 3/NO-5k association with $P$. aeruginosa revealed enhanced bacteria association for Chitosan 2/NO-5k (Figure 3-G, H), confirming the benefits of the cationic/positive properties of Chitosan 2/NO-5k over Chitosan 3/ NO-5k. 
In addition to charge effect, we sought to study the role of molecular weight in $P$. aeruginosa killing. Chitosan oligosaccharides of $\sim 2.5,5$, and $10 \mathrm{kD}$ were synthesized and functionalized with NO (Chitosan 2/NO-2.5 k, Chitosan 2/NO-5 k, Chitosan 2/NO-10 k). As expected, these materials exhibited similar NO-release kinetics (Table 4) due to the similar nitrogen content, allowing for the study of how molecular weight impacts bactericidal efficacy. Regardless of size (i.e., molecular weight), each of the NO-releasing chitosan oligosaccharides (Chitosan 2/NO-2.5 k, Chitosan 2/NO-5 k, Chitosan 2/NO-10 k) exhibited similar bactericidal $\mathrm{NO}$ concentrations (i.e., $\sim 10 \mu \mathrm{mol} \mathrm{NO} / \mathrm{mL}$ ) for 3-log killing (Table 5).

\section{Bactericidal Studies: Biofilms Eradication}

As previously reported, NO-releasing scaffolds have proven effective against both planktonic and biofilm bacteria. [20, 23, 53, 54] For example, Barraud et al. reported that exposing established biofilms to NO (from small molecule NO donors) greatly enhanced the anti-biofilm efficacy of antimicrobial compounds including tobramycin, hydrogen peroxide, and sodium dodecyl sulfate.[54] Hetrick et al. demonstrated the use of macromolecular NOreleasing scaffolds (e.g., $N$-diazeniumdiolate-modified silica particles) to eradicate a broadspectrum of biofilms with comparable or reduced toxicity ( $\sim 80 \%$ viability reduction) against mammalian cells versus currently administered antiseptics (e.g., povidone iodine or chlorhexidine).[53] Based on these prior studies, we expected the NO-releasing chitosan oligosaccharides to also be effective against biofilms with perhaps less toxicity against mammalian cells than other scaffolds (e.g., silica, dendrimers).[55]

To evaluate the anti-biofilm activity of NO-releasing chitosan oligosaccharides (e.g., Chitosan 1/NO-5k, Chitosan 2/NO-5k, Chitosan 3/NO-5k), P. aeruginosa biofilms were exposed to $0.2-1.3 \mathrm{mg} / \mathrm{mL}$ NO-releasing chitosan oligosaccharides for $24 \mathrm{~h}$ (corresponding to $\sim 0.17-0.46 \mu \mathrm{mol} \mathrm{NO} / \mathrm{mL}$ ). After treatment, the biofilms were removed from the silicone rubber substrates by vortexing and sonication to enable viability quantification.[54] Control experiments were performed to confirm the growth of $P$. aeruginosa biofilms using the selected protocol. As shown in Figure 4, the viability of $P$. aeruginosa in the biofilm was $\sim 2 \times 10^{8} \mathrm{CFU}$ when exposed only to PBS. The chitosan concentrations for 5-log reduction of biofilm bacteria viability (MBC) were 400, 700, and $1000 \mu \mathrm{g} / \mathrm{mL}$ for Chitosan 2/NO-5k, Chitosan 1/NO-5k, and Chitosan 3/NO-5k, respectively. Chitosan 2/NO-5k exhibited the greatest anti-biofilm efficacy, a likely result due to both increased NO storage/release and rapid association with the negatively charged bacteria.

Although Chitosan 1/NO-5k and Chitosan 3/NO-5k stored similar levels of NO ( 0.3 $\mu \mathrm{mol} / \mathrm{mg}$ ), Chitosan 1/NO-5k was more effective at eradicating the biofilm bacteria (MBC $700 \mu \mathrm{g} / \mathrm{mL}$ ) compared to Chitosan 3/NO-5k (MBC $1000 \mu \mathrm{g} / \mathrm{mL}$ ). The decreased antibiofilm efficacy for Chitosan 3/NO-5k may result from the shielding of the amine moieties by the neutral PEG chains, thus impeding association with the negatively charged exterior of the bacteria. To confirm this hypothesis, the association of Chitosan 2/NO-5k and Chitosan 3/NO-5k with $P$. aeruginosa biofilm was evaluated using confocal microscope. As shown in Figure 5, biofilms exposed to Chitosan 2/NO-5k exhibited more intense red fluorescence compared to Chitosan 3/NO-5k, again confirming the enhanced association of the positively charged Chitosan $2 / \mathbf{N O}-5 \mathbf{k}$ with the bacteria. The efficient association of chitosan oligosaccharides with bacteria in biofilms is a great advantage over previously reported NO-releasing polysaccharides which are not expected to penetrate the exopolysaccharides matrix due to their insolubility under physiological conditions.

Although chitosan molecular weight was not observed to play a significant role in planktonic killing, less effective bacteria killing was observed when using Chitosan 2/ 
NO-10k, the largest chitosan oligosaccharides $(600 \mu \mathrm{g} / \mathrm{mL}$ vs. $400 \mu \mathrm{g} / \mathrm{mL}$ for Chitosan $2 /$

NO-10k and Chitosan 2/NO-2.5k) against biofilms. The exopolysaccharides matrix is likely slowing the diffusion of the largest chitosan structure. Takenaka et al., previously reported less efficient EPS penetration of high (vs low)-molecular weight dextran,[55] further supporting this hypothesis that the impeded diffusion of Chitosan 2/NO-10k led to slow association with bacteria within the biofilms (Figure 5). Control chitosan oligosaccharides (e.g., Chitosan 1, Chitosan 2, and Chitosan 3) did not lead to a significant reduction in bacterial viability at the same concentrations as their NO-releasing counterparts, indicating that the observed bacterial killing was due to NO from the $N$-diazeniumdiolatefunctionalized chitosan oligosaccharides rather than the chitosan scaffolds themselves.

\section{Cytotoxicity of NO-releasing Chitosan Oligosaccharides to Mammalian Fibroblasts}

The benefit of utilizing chitosan as NO-releasing vehicles includes its non-toxic nature to mammalian cells. The cytotoxicity of control and NO-releasing chitosan oligosaccharides were compared by exposing mouse fibroblast cells to the oligosaccharides at the MBCs against $P$. aerugionsa biofilms noted above.

The normalized cell viabilities of control and NO-releasing chitosan oligosaccharides after $24 \mathrm{~h}$ incubation are shown in Figure 6. Regardless of size (i.e., molecular weight), the control and NO-releasing chitosan oligosaccharides were non-toxic against mouse fibroblast cells at the MBCs for the NO-releasing scaffolds, indicating an advantage of these materials as anti-biofilm agents compared to other antibacterial agents.[53] Of note, the NO-releasing chitosan oligosaccharides exhibited lower cytotoxicity than the chitosan controls, corroborating previous reports that certain levels of NO may promote cell proliferation.[56, 57] Indeed, treatment of mouse lung endothelial cells and human aortic endothelial cells with small molecule NO donors such as $S$-nitroso-L-glutathione (GSNO), $S$-nitroso-Nacetylpenicillamine (SNAP), $N$-diazeniumdiolated-diethyltriamine (DETA/NO) has been shown to promote proliferation.[58, 59] Collectively, the antimicrobial activity against planktonic and biofilm bacterial and the lack of toxicity of NO-releasing chitosan oligosaccharides suggests that NO-releasing chitosan oligosaccharides may serve as ideal antimicrobial agents for applications including wound healing and cystic fibrosis.

\section{CONCLUSION}

This study focused on the synthesis of $\mathrm{N}$-diazeniumdiolate-modified chitosan oligosaccharides with controlled NO storage and tunable NO-release kinetics. The water solubility of chitosan oligosaccharides allows for both beneficial diffusion into biofilms and subsequent association with bacteria, resulting in efficient eradication of biofilm bacteria at concentrations eliciting minimal toxicity to L929 mouse fibroblast cells. Our study demonstrates the potential of NO-releasing chitosan oligosaccharides as antimicrobial agents. Experiments are underway to evaluate the biocidal efficacy of these materials against a broad spectrum of bacteria strains including methicillin-resistant Staphylococcus aureus and cystic fibrosis-related $P$. aeruginosa strains (e.g., mucoid/alginate-producing strains).

\section{Acknowledgments}

Financial support was provided by the National Institute of Health (EB000708). We also thank Dr. Neal Kramacy at the Michael Hooker Microscopy Facility at the University of North Carolina at Chapel Hill for confocal microscopy assistance. 


\section{References}

1. DeQueiroz GA, Day DF. Antimicrobial activity and effectiveness of a combination of sodium hypochlorite and hydrogen peroxide in killing and removing Pseudomonas aeruginosa biofilms from surfaces. J Appl Microbiol. 2007; 103:794-802. [PubMed: 17897181]

2. Nikitkova AE, Haase EM, Scannapieco FA. Taking the starch out of oral biofilm formation: molecular basis and functional significance of salivary alpha-amylase binding to oral streptococci. Appl Environ Microbiol. 2013; 79:416-423. [PubMed: 23144140]

3. Costerton JW, Stewart PS, Greenberg EP. Bacterial biofilms: a common cause of persistent infections. Science. 1999; 284:1318-1322. [PubMed: 10334980]

4. Dowd SE, Wolcott RD, Sun Y, McKeehan T, Smith E, Rhoads D. Polymicrobial nature of chronic diabetic foot ulcer biofilm infections determined using bacterial tag encoded FLX amplicon pyrosequencing (bTEFAP). PLoS One. 2008; 3:e3326. [PubMed: 18833331]

5. Lyczak JB, Cannon CL, Pier GB. Lung infections associated with cystic fibrosis. Clin Microbiol Rev. 2002; 15:194-222. [PubMed: 11932230]

6. Sauer K, Camper AK, Ehrlich GD, Costerton JW, Davies DG. Pseudomonas aeruginosa displays multiple phenotypes during development as a biofilm. J Bacteriol. 2002; 184:1140-1154. [PubMed: 11807075]

7. Wolcott RD, Rhoads DD, Dowd SE. Biofilms and chronic wound inflammation. J Wound Care. 2008; 17:333-341. [PubMed: 18754194]

8. Fux CA, Costerton JW, Stewart PS, Stoodley P. Survival strategies of infectious biofilms. Trends Microbiol. 2005; 13:34-40. [PubMed: 15639630]

9. Keren I, Kaldalu N, Spoering A, Wang Y, Lewis K. Persister cells and tolerance to antimicrobials. FEMS Microbiol Lett. 2004; 230:13-18. [PubMed: 14734160]

10. Smith AW. Biofilms and antibiotic therapy: Is there a role for combating bacterial resistance by the use of novel drug delivery systems? Adv Drug Delivery Rev. 2005; 57:1539-1550.

11. Marletta MA, Tayeh MA, Hevel JM. Unraveling the biological significance of nitric oxide. BioFactors. 1990; 2:219-225. [PubMed: 2282138]

12. MacMicking J, Xie QW, Nathan C. Nitric oxide and macrophage function. Annu Rev Immunol. 1997; 15:323-350. [PubMed: 9143691]

13. Fang FC. Perspectives series: host/pathogen interactions. Mechanisms of nitric oxide-related antimicrobial activity. J Clin Invest. 1997; 99:2818-2825. [PubMed: 9185502]

14. Riccio DA, Schoenfisch MH. Nitric oxide release: part I. macromolecular scaffolds. Chem Soc Rev. 2012; 41:3731-3741. [PubMed: 22362355]

15. Carpenter AW, Schoenfisch MH. Nitric oxide release: part II. therapeutic applications. Chem Soc Rev. 2012; 41:3742-3752. [PubMed: 22362384]

16. Coneski PN, Schoenfisch MH. Nitric oxide release: part III. measurement and reporting. Chem Soc Rev. 2012; 41:3753-3758. [PubMed: 22362308]

17. Nichols SP, Storm WL, Koh A, Schoenfisch MH. Local delivery of nitric oxide: targeted delivery of therapeutics to bone and connective tissues. Adv Drug Deliv Rev. 64:1177-1188. [PubMed: 22433782]

18. Fang FC. Antimicrobial reactive oxygen and nitrogen species: concepts and controversies. Nat Rev Microbiol. 2004; 2:820-832. [PubMed: 15378046]

19. Ghaffari A, Miller CC, McMullin B, Ghahary A. Potential application of gaseous nitric oxide as a topical antimicrobial agent. Nitric Oxide-Biol Chem. 2006; 14:21-29.

20. Hetrick EM, Shin JH, Stasko NA, Johnson CB, Wespe DA, Holmuhamedov E, et al. Bactericidal efficacy of nitric oxide-releasing silica nanoparticles. ACS Nano. 2008; 2:235-246. [PubMed: 19206623]

21. Carpenter AW, Slomberg DL, Rao KS, Schoenfisch MH. Influence of scaffold size on bactericidal activity of nitric oxide-releasing silica nanoparticles. ACS Nano. 2011; 5:7235-7244. [PubMed: 21842899]

22. Lu Y, Sun B, Li C, Schoenfisch MH. Structurally diverse nitric oxide-releasing poly(propylene Imine) dendrimers. Chem Mater. 23:4227-4233. [PubMed: 22053127] 
23. Sun B, Slomberg DL, Chudasama SL, Lu Y, Schoenfisch MH. Nitric oxide-releasing dendrimers as antibacterial agents. Biomacromolecules. 2012; 13:3343-3354. [PubMed: 23013537]

24. Slomberg DL, Lu Y, Broadnax AD, Hunter RA, Carpenter AW, Schoenfisch MH. Role of size and shape on biofilm eradication for nitric oxide-releasing silica nanoparticles. ACS Appl Mater Interfaces. 2013; 5:9322-9329. [PubMed: 24006838]

25. Lu Y, Slomberg DL, Shah A, Schoenfisch MH. Nitric oxide-releasing amphiphilic poly(amidoamine) (PAMAM) dendrimers as antibacterial agents. Biomacromolecules. 2013; 14:3589-3598. [PubMed: 23962307]

26. Zhao H, Serrano MC, Popowich DA, Kibbe MR, Ameer GA. Biodegradable nitric oxide-releasing poly(diol citrate) elastomers. J Biomed Mater Res, Part A. 2010; 93:356-363.

27. Coneski PN, Rao KS, Schoenfisch MH. Degradable nitric oxide-releasing biomaterials via postpolymerization functionalization of cross-linked polyesters. Biomacromolecules. 2010; 11:32083215.

28. Wold KA, Damodaran VB, Suazo LA, Bowen RA, Reynolds MM. Fabrication of biodegradable polymeric nanofibers with covalently attached NO donors. ACS Appl Mater Interfaces. 2012

29. Damodaran VB, Reynolds MM. Biodegradable S-nitrosothiol tethered multiblock polymer for nitric oxide delivery. J Mater Chem. 2011; 21:5870-5872.

30. Dash M, Chiellini F, Ottenbrite RM, Chiellini E. Chitosan-a versatile semi-synthetic polymer in biomedical applications. Prog Polym Sci. 2011; 36:981-1014.

31. Jayakumar R, Prabaharan M, Nair SV, Tamura H. Novel chitin and chitosan nanofibers in biomedical applications. Biotech Adv. 2010; 28:142-150.

32. Valmikinathan CM, Mukhatyar VJ, Jain A, Karumbaiah L, Dasari M, Bellamkonda RV. Photocrosslinkable chitosan based hydrogels for neural tissue engineering. Soft Matter. 2012; 8:1964-1976.

33. Zhang JL, Xia WS, Liu P, Cheng QY, Tahirou T, Gu WX, et al. Chitosan modification and pharmaceutical/biomedical applications. Mar Drugs. 2010; 8:1962-1987. [PubMed: 20714418]

34. Wan A, Gao Q, Li HL. Effects of molecular weight and degree of acetylation on the release of nitric oxide from chitosan-nitric oxide adducts. J Appl Polym Sci. 2010; 117:2183-2188.

35. Wan A, Sun Y, Li HL. Characterization of folate-graft-chitosan as a scaffold for nitric oxide release. Int J Biol Macromol. 2008; 43:415-421. [PubMed: 18708088]

36. Smith, DJ.; Yazici, S. Chitosan-based nitric oxide donor compositions. US Patent No. 6451337. 2002.

37. Du J, Hsieh YL. Nanofibrous membranes from aqueous electrospinning of carboxymethyl chitosan. Nanotechnology. 2008:19.

38. Kim SK, Rajapakse N. Enzymatic production and biological activities of chitosan oligosaccharides (COS): A review. Carbohydr Polym. 2005; 62:357-368.

39. Maghami GG, Roberts GAF. Evaluation of the viscometric constants for chitosan. Makromol Chem. 1988; 189:195-200.

40. Wong K, Sun GB, Zhang XQ, Dai H, Liu Y, He CB, et al. PEI-g-chitosan, a novel gene delivery system with transfection efficiency comparable to polyethylenimine in vitro and after liver administration in vivo. Bioconjugate Chem. 2006; 17:152-158.

41. Tokura S, Ueno K, Miyazaki S, Nishi N. Molecular weight dependent antimicrobial activity by chitosan. Macromol Symp. 1997; 120:1-9.

42. Tokoro A, Tatewaki N, Suzuki K, Mikami T, Suzuki S, Suzuki M. Growth-inhibitory effect of hexa-N-acetylchitohexaose and chitohexaose against Meth-a solid tumor. Chem Pharm Bull. 1988; 36:784-790. [PubMed: 3409386]

43. Pae HO, Seo WG, Kim NY, Oh GS, Kim GE, Kim YH, et al. Induction of granulocytic differentiation in acute promyelocytic leukemia cells (HL-60) by water-soluble chitosan oligomer. Leukemia Res. 2001; 25:339-346. [PubMed: 11248331]

44. Porporatto C, Bianco ID, Riera CM, Correa SG. Chitosan induces different L-arginine metabolic pathways in resting and inflammatory macrophages. Biochem Biophys Res Commun. 2003; 304:266-272. [PubMed: 12711309] 
45. Hirano S. Chitin biotechnology applications. Biotechnol Annu Rev. 1996; 2:237-258. [PubMed: 9704098]

46. Xu JG, Zhao XM, Wang XL, Zhao ZB, Du YG. Oligochitosan inhibits Phytophthora capsici by penetrating the cell membrane and putative binding to intracellular targets. Pestic Biochem Physiol. 2007; 88:167-175.

47. Hu FQ, Liu LN, Du YZ, Yuan H. Synthesis and antitumor activity of doxorubicin conjugated stearic acid-g-chitosan oligosaccharide polymeric micelles. Biomaterials. 2009; 30:6955-6963. [PubMed: 19782395]

48. Stasko NA, Schoenfisch MH. Dendrimers as a scaffold for nitric oxide release. J Am Chem Soc. 2006; 128:8265-8271. [PubMed: 16787091]

49. Davies KM, Wink DA, Saavedra JE, Keefer LK. Chemistry of the diazeniumdiolates. 2. kinetics and mechanism of dissociation to nitric oxide in aqueous solution. J Am Chem Soc. 2001; 123:5473-5481. [PubMed: 11389629]

50. Hetrick EM, Shin JH, Stasko NA, Johnson CB, Wespe DA, Holmuhamedov E, et al. Bactericidal efficacy of nitric oxide-releasing silica nanoparticles. ACS Nano. 2008; 2:235-246. [PubMed: 19206623]

51. Lu Y, Slomberg DL, Sun B, Schoenfisch MH. Shape- and nitric oxide fux-dependent bactericidal activity of nitric oxide-releasing silica nanorods. Small. 2013; 9:2189-2198. [PubMed: 23362159]

52. Pruitt BA, McManus AT, Kim SH, Goodwin CW. Burn wound infections: current status. World J Surg. 1998; 22:135-145. [PubMed: 9451928]

53. Hetrick EM, Shin JH, Paul HS, Schoenfisch MH. Anti-biofilm efficacy of nitric oxide-releasing silica nanoparticles. Biomaterials. 2009; 30:2782-2789. [PubMed: 19233464]

54. Barraud N, Hassett DJ, Hwang SH, Rice SA, Kjelleberg S, Webb JS. Involvement of nitric oxide in biofilm dispersal of Pseudomonas aeruginosa. J Bacteriol. 2006; 188:7344-7353. [PubMed: 17050922]

55. Takenaka S, Pitts B, Trivedi HM, Stewart PS. Diffusion of Macromolecules in Model Oral Biofilms. Appl Environ Microbiol. 2009; 75:1750-1753. [PubMed: 19168660]

56. Al-Ani B, Hewett PW, Ahmed S, Cudmore M, Fujisawa T, Ahmad S, et al. The release of nitric oxide from S-nitrosothiols promotes angiogenesis. PLoS One. 2006:1.

57. Cooke JP, Losordo DW. Nitric oxide and angiogenesis. Circulation. 2002; 105:2133-2135. [PubMed: 11994243]

58. Kawasaki K, Smith RS Jr, Hsieh CM, Sun J, Chao J, Liao JK. Activation of the phosphatidylinositol 3-kinase/protein kinase Akt pathway mediates nitric oxide-induced endothelial cell migration and angiogenesis. Mol Cell Biol. 2003; 23:5726-5737. [PubMed: 12897144]

59. MacLauchlan S, Yu J, Parrish M, Asoulin TA, Schleicher M, Krady MM, et al. Endothelial nitric oxide synthase controls the expression of the angiogenesis inhibitor thrombospondin 2. Proc Natl Acad Sci U S A. 108:E1137-1145. [PubMed: 21949402] 


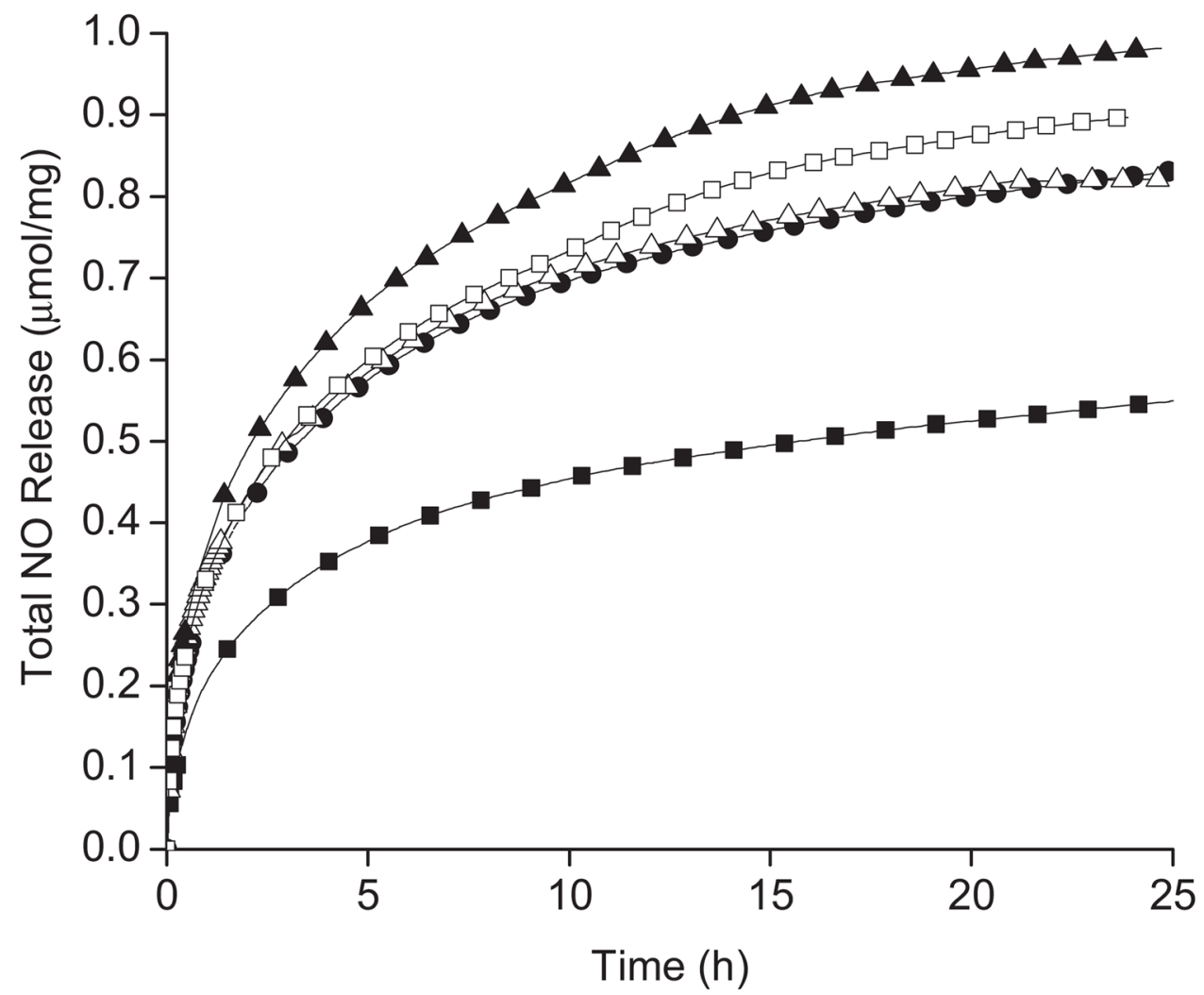

Figure 1.

Nitric oxide release profiles of Chitosan 2/NO-5k in methanol (solid square), methanol/ water 9:1 (solid circle), 8:2 (open triangle), 7:3 (solid triangle), and 6:4 v/v (open square). 

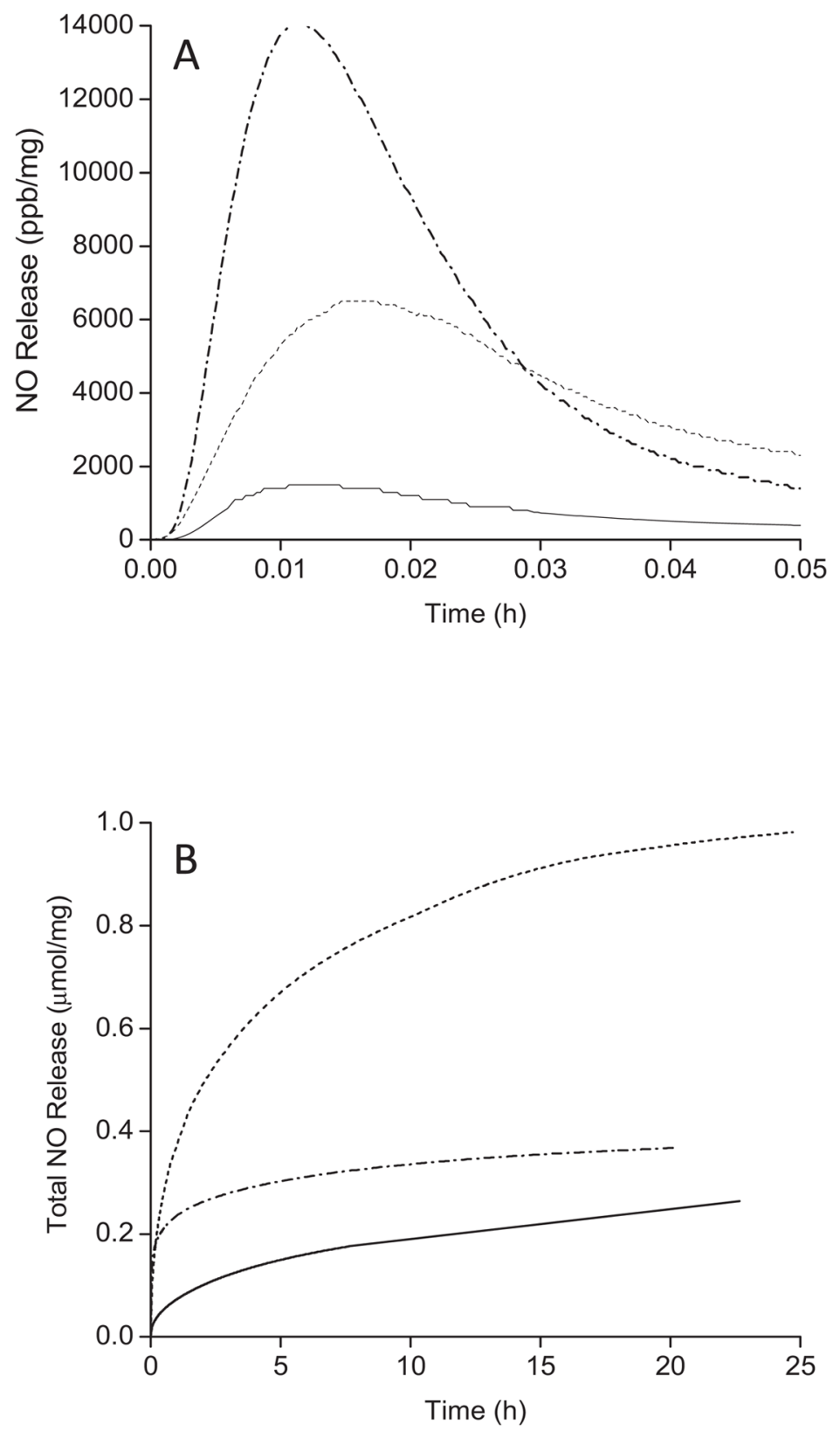

Figure 2.

Real-time NO release profiles (A) and plot of t[NO] vs time (B) for NO-releasing chitosan oligosaccharides (e.g., Chitosan 1-5k (solid line), Chitosan 2-5k (dot line), and Chitosan 3-5k (dash dot line)). 


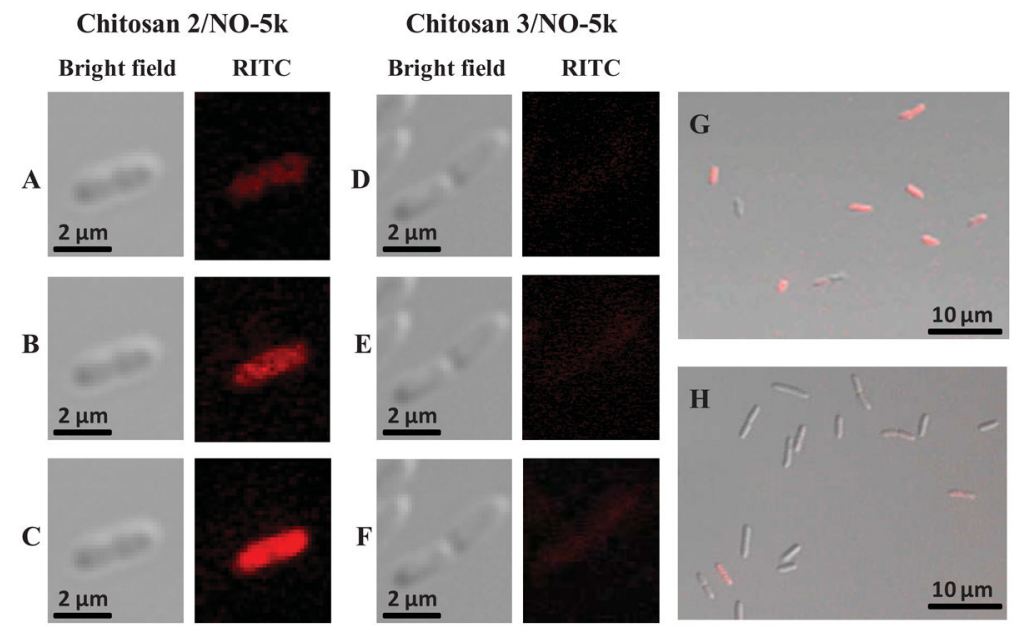

Figure 3.

Bright field and fluorescent images of RITC-modified Chitosan 2/NO-5k $\left(150 \mu \mathrm{g} \mathrm{mL}^{-1}\right)$ at A) 24, B) 28, C) 42 min and Chitosan 3/NO-5k (150 $\mathrm{g} \mathrm{mL}^{-1}$ ) at D) 82, E) 86, F) 110, H) 120 min association with $P$. aeruginosa. Overlay images of $P$. aeruginosa incubated with G) Chitosan 2/NO-5k at $44 \mathrm{~min}$ and H) Chitosan 2/NO-5k at $120 \mathrm{~min}$. 


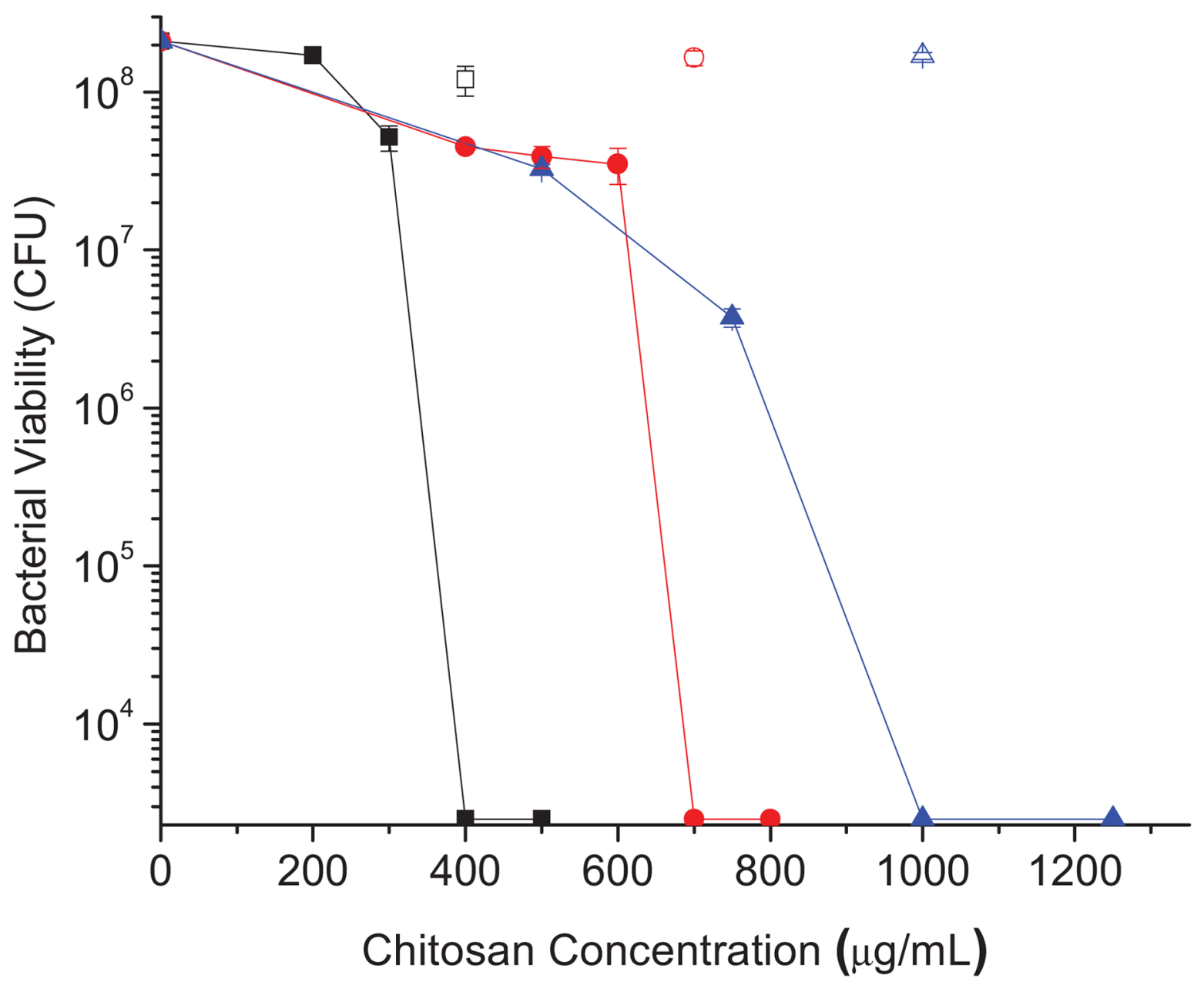

Figure 4.

Anti-biofilm efficacy of NO-releasing (solid symbols) and control (open symbols) chitosan oligosaccharides (Chitosan 1-5k (sphere), Chitosan 2-5k (square), and Chitosan 3-5k (triangle)) against established $P$. aeruginosa biofilms. Control chitosan oligosaccharides did not affect the bacteria viability. 

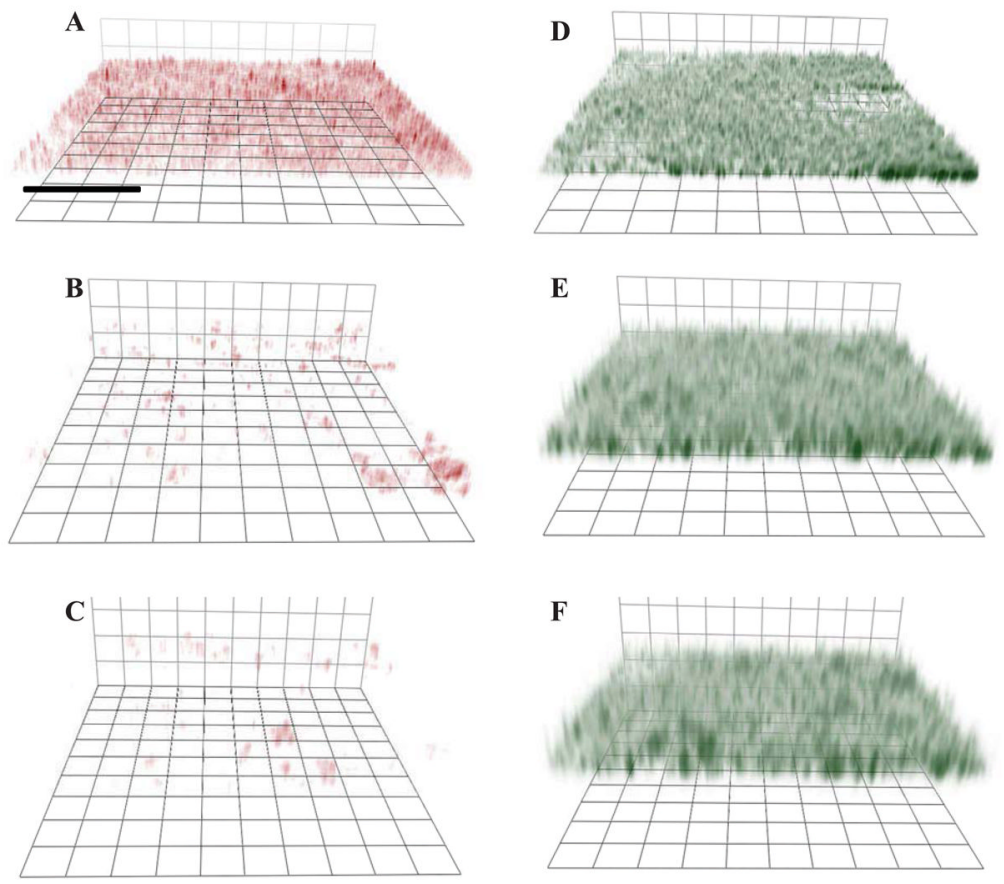

Figure 5.

Confocal fluorescence images of RITC-labeled chitosan oligosaccharide association with $P$. aeruginosa in biofilms: A) Chitosan 2/NO-5k, B) Chitosan 3/NO-5k, C) Chitosan 2-10k) and images of syto 9 labeled biofilms incubated with D) Chitosan 2/NO-5k, E) Chitosan 3/ NO-5k and F) Chitosan 2/NO-10k. Scale bar: $40 \mu \mathrm{m}$. The green fluorescence of syto 9 indicates that the $P$. aeruginosa bacteria are embedded within the biofilms. Red fluorescence of RITC indicates the association of RITC-labeled chitosan oligosaccharides with $P$. aeruginosa in biofilms. 


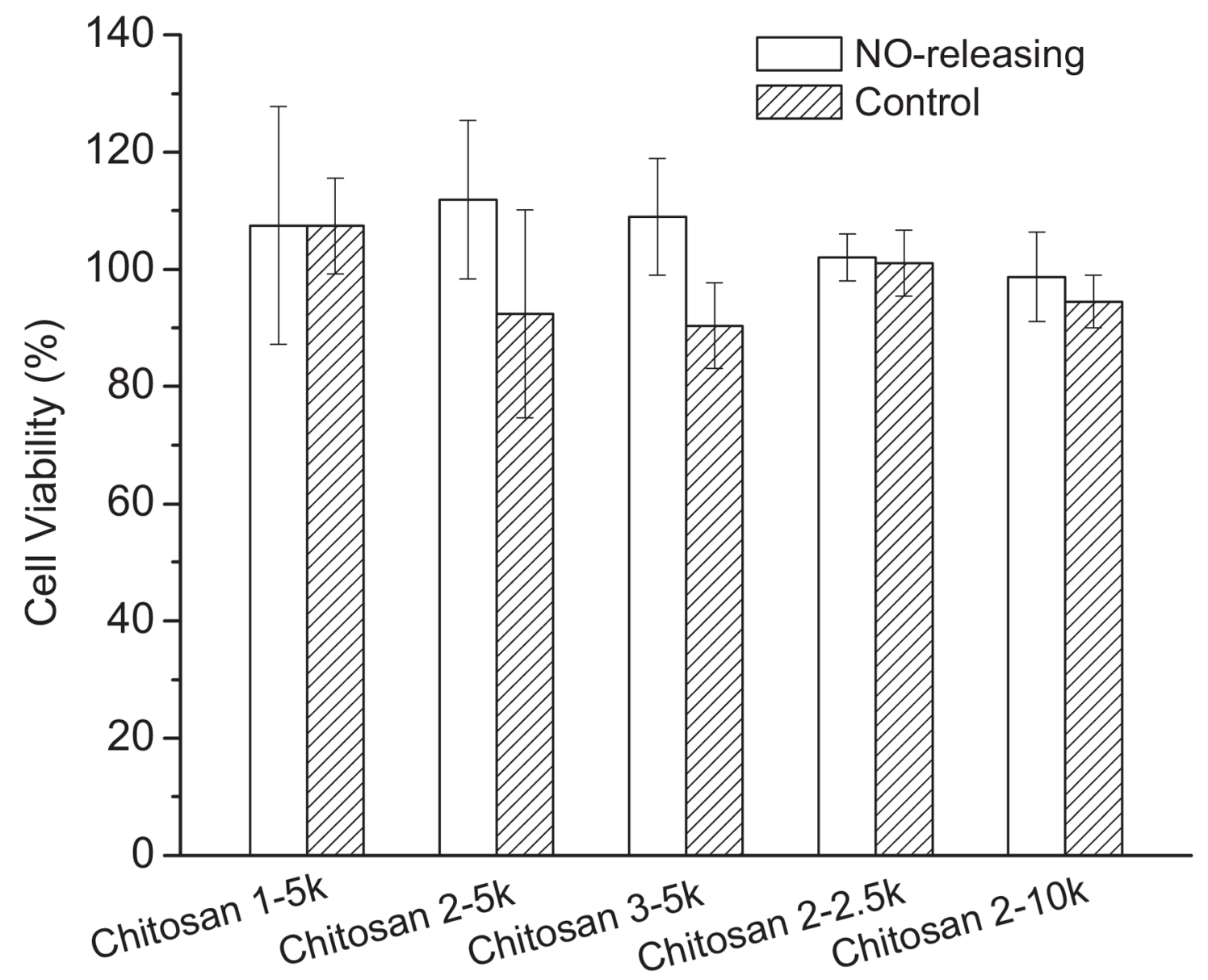

Figure 6.

Viability of L929 mouse fibroblasts exposed to control and NO-releasing chitosan oligosaccharides at concentration required to kill biofilm bacteria (MBC). Studies consisted of at least three experiments with error bars representing standard deviation. 
A

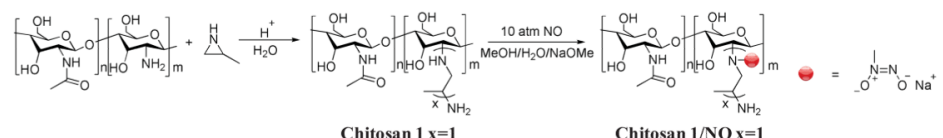

Chitosan $1 x=1$
Chitosan 2 $x=2$

Chitosan $1 / \mathrm{NO} x=1$

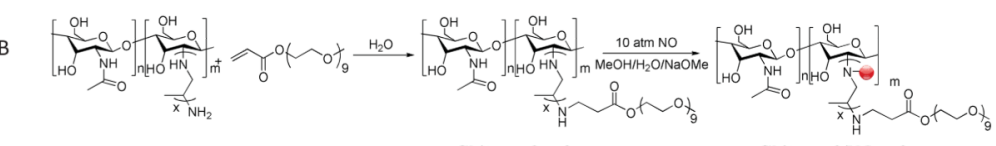

Chitosan $3 \mathrm{x}=2$

Chitosan 3/NO $x=2$

Scheme 1.

Synthesis of secondary amine- and $N$-diazeniumdiolate-functionalized chitosan

oligosaccharide derivatives. A) Grafting of 2-methyl aziridine onto primary amines of chitosan oligosaccharides (Chitosan 1 and Chitosan 2) and subsequent $\mathrm{N}$-diazeniumdiolate formation of the resulting materials (Chitosan 1/NO and Chitosan 2/NO); B) PEGylation of 2-methyl aziridine-grafted-chitosan oligosaccharide (Chitosan 3) with NO donor functionalization (Chitosan 3/NO). 


\section{Table 1}

Degradation conditions of chitosan oligosaccharides of different molecular weights.

\begin{tabular}{lccc}
\hline Chitosan oligosaccharides & $\mathbf{M}_{\mathbf{v}}{ }^{\boldsymbol{a}}$ & $\mathbf{T}\left({ }^{\circ} \mathbf{C}\right)$ & {$\left[\mathbf{H}_{2} \mathbf{O}_{2}\right](\mathbf{w t} \%)$} \\
\hline $2.5 \mathrm{k}$ & 2657 & 85 & 30 \\
$5 \mathrm{k}$ & 5370 & 85 & 15 \\
$10 \mathrm{k}$ & 10142 & 65 & 15 \\
\hline
\end{tabular}

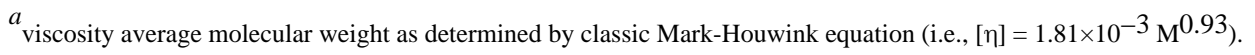




\section{Table 2}

Elemental (CHN) analysis of chitosan oligosaccharides and secondary amine-functionalized derivatives.

\begin{tabular}{lccc}
\hline Materials & $\mathbf{C}(\%)$ & $\mathbf{H}(\%)$ & $\mathbf{N}(\%)$ \\
\hline Chitosan oligosaccharides $^{a}$ & $42.2 \pm 1.6$ & $6.8 \pm 0.1$ & $6.3 \pm 0.2$ \\
Chitosan 1-5k $_{\text {Chitosan 2-5k }}$ & $43.5 \pm 1.2$ & $7.7 \pm 0.3$ & $8.9 \pm 0.1$ \\
Chitosan 3-5k & $44.7 \pm 1.8$ & $8.4 \pm 0.2$ & $10.8 \pm 0.8$ \\
Chitosan 2-2.5k & $51.0 \pm 0.2$ & $9.0 \pm 0.2$ & $3.1 \pm 0.1$ \\
Chitosan 2-10k & $43.7 \pm 0.7$ & $8.5 \pm 0.2$ & $10.9 \pm 0.1$ \\
\hline
\end{tabular}

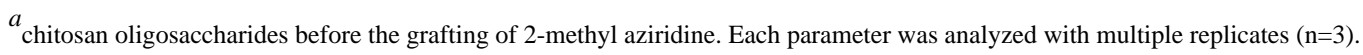




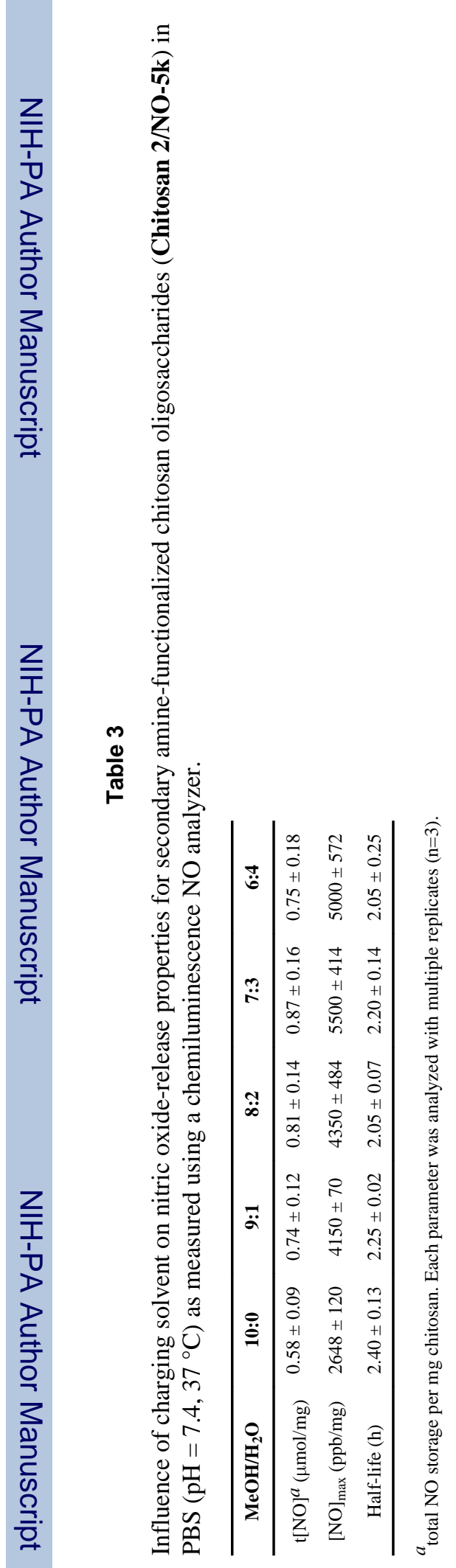




\section{Table 4}

Nitric oxide-release properties of different $N$-diazeniumdiolate NO donor-functionalized chitosan oligosaccharides in $\mathrm{PBS}\left(\mathrm{pH}=7.4,37^{\circ} \mathrm{C}\right.$ ) as measured using a chemiluminescence NO analyzer.

\begin{tabular}{lcccc}
\hline Material & $\mathbf{t}[\mathbf{N O}]^{a}(\mu \mathbf{m o l} / \mathbf{m g})$ & $\mathbf{t}[\mathbf{N O}]^{b}(\mu \mathbf{m o l} / \mathbf{m g})$ & {$[\mathbf{N O}]_{\max }(\mathbf{p p b} / \mathbf{m g})$} & $\mathbf{t}_{\mathbf{1 / 2}}(\mathbf{h})$ \\
\hline Chitosan 1/NO-5 k & $0.30 \pm 0.04$ & $0.16 \pm 0.03$ & $1600 \pm 215$ & $3.60 \pm 0.13$ \\
Chitosan 2/NO-5 k & $0.87 \pm 0.16$ & $0.52 \pm 0.15$ & $5500 \pm 414$ & $2.20 \pm 0.14$ \\
Chitosan 3/NO-5 k & $0.35 \pm 0.02$ & $0.29 \pm 0.01$ & $12600 \pm 2121$ & $0.15 \pm 0.01$ \\
Chitosan 2/NO-2.5 k & $0.84 \pm 0.04$ & $0.49 \pm 0.02$ & $7500 \pm 550$ & $2.06 \pm 0.10$ \\
Chitosan 2/NO-10 k & $0.81 \pm 0.05$ & $0.47 \pm 0.03$ & $7350 \pm 672$ & $2.04 \pm 0.05$ \\
\hline
\end{tabular}

$a_{\text {total NO released and }}$

${ }^{b}$ NO released over 24 and $4 \mathrm{~h}(\mu \mathrm{mol})$ per milligram of chitosan oligosaccharides. Charging solvent used was methanol/water 7:3 v/v. Each parameter was analyzed with multiple replicates $(n=3)$. 


\section{Table 5}

Minimum bactericidal concentration (MBC) and NO doses of NO-releasing chitosan oligosaccharides for 3$\log$ reduction in planktonic $P$. aeruginosa viability.

\begin{tabular}{lcc}
\hline Chitosans & MBC $(\mu \mathrm{g} / \mathbf{m L})$ & NO dose $(\mu \mathbf{m o l} / \mathbf{m L})$ \\
\hline Chitosan 1/NO-5k & 2000 & 0.32 \\
Chitosan 2/NO-5k & 200 & 0.10 \\
Chitosan 3/NO-5k & 1500 & 0.45 \\
Chitosan 2/NO-2.5k & 250 & 0.12 \\
Chitosan 2/NO-10k & 250 & 0.12 \\
\hline
\end{tabular}

